\title{
Konturer af intermedial litteratur og litteraturdidaktik i Fælles Mål og i danskundervisningen
}

\section{Ayoe Quist Henkel. Lektor i dansk og ph.d.i børnelitteratur, aqh@via.dk VIA University College}

\begin{abstract}
Resumé
I Fælles Mål for faget dansk (2014a) forekommer vendingen "litteratur og andre æstetiske tekster" og begrebet "multimodalitet" for første gang i danskfagets læreplan. Samtidig udvikles nye former for kunstarter og medier for realisering af litteratur i kraft af den teknologiske og digitale udvikling. Når børn i dag åbner en litterær tekst i danskundervisningen, vil det af og til være i form af digital litteratur, som fx en litterær app, en sms-novelle eller et andet digitalt format, der benytter sig af forskellige udtryksformer og varierende former for interaktion. Sådanne forandringer i læreplanen og i det litterære felt stiller nye spørgsmål til dels, hvad der karakteriserer litteraturundervisningens genstandsfelt, dels hvorfor og hvordan digital litteratur kan læses i modersmålsundervisningen. Disse fagdidaktiske spørgsmål diskuterer og svarer artiklen på ud fra en intermedialitetstilgang (bl.a. Mitchell, 1994; Wolf, 2007; Elleström, 2010; Bruhn, 2012 og 2016), eftersom denne i al sin diversitet er optaget af tværæstetisk og tværmedial betydningsdannelse i blandt andet litteratur. Denne tilgang komplementerer dermed multimodalitetsteorien, der orienterer sig mod alle tekster og deres sammensatte og kommunikative hensigt, ved at fokusere særligt på æstetiske tekster og disses mulige refleksions- og erkendelsespotentiale. Ud fra en analyse fokuseret på de to nye begrebsanvendelser og med nedslag $i$ en digital og remedieret version af Karen Blixens fortælling "De blå øjne" (2016) tegner artiklen konturerne af intermedial litteraturdidaktik, der afslutningsvis formuleres i tre praksisnære principper for litteraturundervisning: Sanse, sammenligne og skabe.
\end{abstract}

\section{Nøgleord}

Fagdidaktik, danskfaget, digital litteratur, litteratur for børn og unge, intermedialitet, multimodalitet, litteraturundervisning, Fælles Mål for faget dansk, remediering

\section{Artiklen er fagfællebedømt}

\section{Anslag: Litteratur i skolen i bevægelse}

Med fingrene bevæger eleven det, der minder om lysskæret fra en lygte, hen over computeren eller tabletten for at læse ordene, der står på skærmen, og som

Årg. 2 | nr. 2 | 2017 | Side 106-127 | https://tidsskrift.dk/index.php/SLP/index ISSN: 2445-8538 | For artikler publiceret i LUP tillades at læsere kan downloade, kopiere, distribuere, udskrive, søge eller linke til og citere fra til ethvert lovligt formål. LUP tillader således ikke at læsere bruger artikler eller dele af dem i egne artikler uden at citere, eller på anden vis anvender dem til kommercielle formål. 
samtidig bliver læst højt (illustration 1). Her låner læseren hovedpersonen Severines synsvinkel helt konkret for en stund, hvor hun desperat og i mørke lister sig ned på havnen med en lygte i hånden for at tage galionsfigurens safirøjne. I et narrativt klimaks akkompagneres ordene af en ildevarslende lyd, ligesom utallige øjne dukker op på skærmen, hvis læseren berører den (illustration 2). Her bliver distancen mellem kvinden og skipperen visuelt tydelig, da de står langs hver sin kant af skærmen, ligesom deres blikretninger fører væk fra hinanden. Samtidig bliver fortællingens ledemotiv i form af øjet særligt påtrængende, når eller hvis læseren berører skærmen. Dette er to nedslag i en remedieret version af Karen Blixens fortælling "De blå øjne" fra 1942. "De blå øjne" eksemplificerer, hvordan den samme fortælling kan bevæge sig imellem forskellige former og medier, idet den findes i flere skriftlige udgaver, i Blixens egen mundtlige fortælling og senest i en digital udgave, som er karakteriseret ved, at flere udtryksformer arbejder sammen om at fortælle. I dette eksempel drejer det sig om skrift, billede, lyd, musik og enkelte animationer, der sammen med interaktivitet henvender sig til læseren i en fortælling, der blandt andet drejer sig om, hvad der kan ske, hvis man ikke forstår hinanden, ikke lever livet som det nu engang udfolder sig eller forgriber sig på tilværelsen.



Illustration 1 Blixen "De blå øjne" (2016).

Illustration 2 Blixen "De blå øjne"

Den seneste version af "De blå øjne" er et eksempel på nye, digitale litterære formater for børn og unge (Christensen, 2014; Schwebbs, 2014; Stichnote, 2014; Turrión, 2014; Henkel, 2015; Manresa \& Real, 2015). Sådanne nye tekster stiller spørgsmål til, hvordan vi tilgår, forstår og analyserer litteratur, og de stiller spørgsmål til, hvorfor og hvordan denne digitale litteratur kan indgå i danskundervisningen. I artiklen vil disse nyere litterære formater 
Konturer af intermedial litteratur og litteraturdidaktik i Fælles Mål og ...

blive karakteriseret som digital litteratur for børn og anskuet ud fra en intermedial tilgang ${ }^{1} \mathrm{i}$ bestræbelsen på at svare på disse spørgsmål.

\section{Introduktion}

Intermedialitet skal her forstås som et afgørende element i mediers betydningsdannelse (Elleström, 2010; Bruhn, 2010 og 2016) og kan ifølge Elleström danne "a medial complex integrating materiality, perception and cognition" (Ellestrøm, 2010, s. 15), som kun kan blive forstået og begrebet i samspillet mellem medie og recipient. Netop samspillet mellem medie og recipient eller mellem værk og læser får anderledes forudsætninger, når den litterære tekst er digital og indlejret som et program i fx en tabletcomputer og dennes interface, hvilket også har litteraturdidaktiske konsekvenser. På samme måde får litteratur forstået som "fiktion, formet sprog og livstolkning" (Ringgaard, 2014, s. 31) også anderledes forudsætninger i kraft af digitale muligheder for at benytte flere udtryksformer end skrift og interaktivitet og dermed benytte forskellige sanseappeller som den visuelle, auditive og taktile. Sådanne forandringer i det litterære og mediemæssige felt ser ud til at blive tematiseret med de to nye begrebsanvendelser "litteratur og andre æstetiske tekster" og "multimodalitet" i Fælles Mål for faget dansk (Undervisningsministeriet 2014a, b og c). I artiklen her vil jeg derfor analysere litteraturforståelsen i læreplanen i spændingsfeltet imellem en multimodal og intermedial tekstforståelse, idet den multimodale tilgang indoptager nye teksters forskelligartede kommunikationsformer, men ikke den form for kommunikation, som kunst i særdeleshed og litteratur mere specifikt også kan være. Hvor den multimodale tilgang tilbyder en teori om sammensatte tekster og deres forskellige semiotiske ressourcer, tilbyder den intermediale tilgang en teori om

1 I princippet kan al litteratur anses som værende intermedial litteratur (Bruhn, 2016), men i artiklen her fokuserer jeg på digital litteratur for børn.

2 Litteratur er et flertydigt begreb. Ringgaard har fire definitioner i Litteratur (2014), som indoptager dels mediehistoriske og dels institutionelle elementer. Jeg anvender den citerede definition, idet den ligger i tråd med vejledningens definition i Fælles Mål for faget dansk: "Litteratur er ordkunst, en særlig æstetisk måde at bruge sproget på og dets stilistiske virkemidler. Det er vigtigt at holde fast i denne pointe, så litteraturen ikke alene fremstår som formidler af en bestemt samfundsmæssig holdning eller problemstilling" (Undervisningsministeriet, 2014c). Denne definition kan diskuteres og anskues som værende for snæver. I børnelitterær forskning har blandt andre Anna Karlskov Skyggebjerg undersøgt og understreget vigtigheden af også at inkludere faglitteratur i litteraturbegrebet (Skyggebjerg, 2011). Når jeg baserer litteraturbegrebet $i$ artiklen her på fiktion, er det ikke for at udgrænse faglitteratur, men for at bevare fokus for artiklen. 
fiktion som en mulig æstetisk erkendelsesform. De to tilgange er dermed ikke hinandens modsætninger, men kan komplementere hinanden, og de aktualiserer diskussioner om danskfagets fundering indenfor rammerne af såvel et hermeneutisk, kultur- og litteraturvidenskabeligt fag som et kommunikativt og sprogvidenskabeligt fag (Krogh, 2003; Sørensen, 2008; Illum Hansen, 2015). Artiklen vil dermed diskutere dele af danskfagets legitimeringsgrundlag med henblik på at tegne konturerne af en intermedial litteraturdidaktik. "De blå øjne" vil eksemplificere det nye litterære genstandsfelt, og Fælles mål for dansk vil udgøre det faglige lovgrundlag. På den baggrund operationaliseres den intermediale tilgang afslutningsvis ind i tre praksisnære principper for litteraturundervisning - sansning, sammenligning og skabelse - med "De blå øjne" som eksempel.

\section{Digital litteratur for børn i en intermedial forståelsesramme}

Digital litteratur er karakteriseret ved at "go beyond what could be done without digital media" (Simanowski, 2008, s. 3), hvilket med Simanowski vil sige, at digital litteratur er mere og andet end 'blot' litteratur, for ellers ville det bare være litteratur formidlet i digitale medier (ibid.). En mere udfoldet definition tilbyder Digital Fiction International Network ved at betone, at digital litteratur er "fiction [that is] written for and read on a computer screen [and] that pursues its verbal, discursive and/or conceptual complexity through the digital medium, and would lose something of its aesthetic and semiotic function if it were removed from that medium" (Bell et al., 2010). Med andre ord udnytter digital litteratur "den digitale teknologien $i$ produksjons-, distribusjons- og resepsjonsprosessen" (Rustad, 2012, s. 11). I forlængelse af disse definitioner bliver det imidlertid nødvendigt at præcisere, hvad der mere præcist kendetegner denne overskridelse af papirbåret litteratur og den betonede særlige æstetiske og semiotiske funktion og mulige anderledes reception, som digital litteratur kan besidde, hvilket den intermediale forståelsesramme kan.

Med den intermediale tilgang kan man pointere, at selvom digital litteratur er yderst forskelligartet og baserer sig på forskellige æstetiske udtryksformer og strategier, indeholder den næsten altid, i kraft af en ofte forekommende samtidig tilstedeværelse af disse forskelligartede udtryksformersom fx skrift, billede og lyd. I den remedierede version af "De blå øjne" har ordene - skriftlige som mundtlige - en særlig dominans, men de 
indgår i forskellige samspil med andre æstetiske udtryksformer og interaktion. Generelt har skriften ikke altid primat i digital litteratur. I den digitale udgave af Blixens fortælling bliver øjet som ledemotiv særlig centralt pga. dets visuelle fremtræden både konkret og animeret på "forsiden"/det første opslag (se illustration 3) og grafisk med øjesilhouetten, der kommer frem imellem opslagene, når læseren "bladrer", ligesom fx personers placering på et opslag har betydning for tolkningen af deres relation. Lydligt understøtter bl.a. en hjertebanken og underlægningsmusik fortællingens stemning og personernes følelsesliv. Generelt er digital litteratur karakteriseret ved udforskning af fortælleformer, æstetiske virkemidler og måder at invitere til interaktion på og henter impulser fra såvel den almene populærkultur som fra både klassiske og avantgardistiske strømninger indenfor litteratur, film, billedkunst og musik. Dertil kommer interaktiviteten i form af forskellige måder at invitere læseren til helt konkret at tage del i fortællingen på eller gøre noget for at drive fortællingen videre. I "De blå øjne" sker dette fx ved som tidligere nævnt at illudere, at læseren fører en lygte hen over skærmen for at kunne se skærmbilledet, eller på et andet opslag, hvor læseren visuelt og lydligt inviteres til at berøre tekstbilledet, der herefter krakelerer og dermed bebuder noget ildevarslende (se illustration 4).

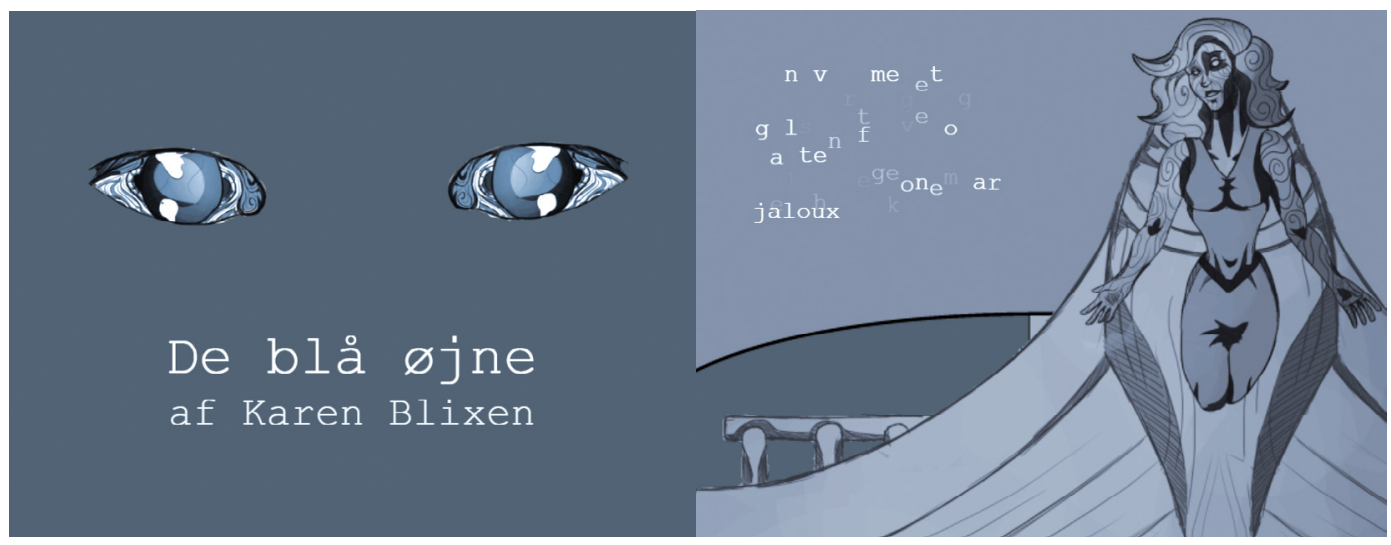

Illustration 3 Blixen "De blå øjne" (2016)

Illustration 4 Blixen "De blå øjne" (2016)

Intermedialitetsforskning tager ofte afsæt i den amerikanske kunsthistoriker W.J.T. Mitchell (fx i Ellestrøm, 2010, s. 14-15; Rippl, 2015, s. 3 og Bruhn 2016, s. 15-16 og 21) og hans pointering af, at alle kunstarter er sammensatte og "mixed media, combining different codes, discursive conventions, channels, sensory and cognitive modes" (Mitchell, 1994, s. 94-95). Denne præmis understreger alle medier og kunstformers grundlæggende forbundne, kom- 
positte og dermed intermediale kvaliteter. Den intermediale tilgang betoner, at en udtryksform principielt altid har et mellemværende med andre udtryksformer i den enkelte tekst, der giver sig udslag i komplekse sansebaserede henvendelser.

Intermedialitetsforskning er et bredt felt, der har udviklet sig siden 1980'erne og forgrener sig til forskellige discipliner som litteratur-, musikog medievidenskab, kunsthistorie, sociologi og filosofi (se fx Rippl, 2015) og er dermed tværdisciplinær per se. Derfor er det ikke muligt eller hensigtsmæssigt at udvikle én definition, ligesom termen står i tæt relation til begreber som blandt andre remediering og multimodalitet, hvilket uddybes senere. Forskning i intermedialitet placerer sig dermed i et divergent felt, og her tager jeg udgangspunkt i den overvejende kunstorienterede forskning i intermedialitet (fx Mitchell, 1994; Rajewsky, 2002; Wolf, 2007; Clüver, 2007; Elleström, 2010 og Bruhn, 2012 og 2016), eftersom denne del af forskningen i al sin diversitet er optaget af, hvordan medie- og kunstformer indgår i forskellige relationer i det enkelte værk og går på tværs imellem mediale fænomener. Den intermediale tilgang orienterer sig mod den betydningsdannelse og det erkendelsespotentiale, der fremkommer, når ét eller flere af følgende dimensioner er til stede i en litterær tekst:

- Elementer fra forskellige medier er repræsenteret i den litterære tekst på det diegetiske niveau, altså på handlingsniveauet/de litterære karakterers verden. Det kan være musikfragmenter, reklameslogans, sms-beskeder og lignende. Sådanne spor af andre medietekster kan have konsekvenser for subjektforståelse og -konstruktion i de litterære værker og inviterer til refleksioner over mediers rolle i tilværelsen hos læseren (mere herom i Henkel, 2016).

- Der er samtidighed mellem eller kombinationer af forskellige udtryksformer som skrift, musik, lyd, stillbilleder, levende billeder, tale og forskellige måder at skabe interaktion på i den enkelte litterære tekst.

- Bogmediet går i dialog med andre medier, hvilket kan iagttages ved fx bogobjekter eller en del digital litteratur, der leger med andre medier eller i sin fysikalitet indoptager andre medier. Hermed tillægges mediet, som værket realiseres i, en afgørende og hidtil ikke særlig synlig rolle i betydningsdannelsen og læseprocessen. 
Disse tre dimensioner af intermedialitet viser denne tilgangs mangesidethed. ${ }^{3}$ Den intermediale tilgang er optaget af såvel tekstinterne som teksteksterne forhold og orienterer sig derfor både mod et værks indre sammensathed og dette værks relation til samtidige medier og den kulturelle kontekst. Denne situerethed og dermed tekstens måde at være i verden på får nogle særlige implikationer, når det drejer sig om litteraturlæsning på fx tabletcomputere i undervisningen. Den digitale version af "De blå øjne" placerer sig overvejende i punkt $b$, idet den skaber oplevelse og betydning i samspillet imellem forskellige udtryksformer og læserens interaktion med interfacet, dvs. grænse- og kontaktfladen mellem tabletcomputeren og læseren. Dermed bliver der lagt vægt på fortællingens stemning og univers og dens udsagn om at være menneske i verden, der fremkommer i udtryksformernes interaktion med hinanden og i læserens interaktion med teksten. Intermedial litteratur realiseret $i$ et multisensorisk interface medfører, at teksten i mindre grad er et stabilt objekt for fortolkning og derfor snarere en teksthændelse. I "De blå øjne" er der som i punkt a) spor af andre medietekster, fx et klassisk musiknummer og den grafiske æstetik, hvor blandt andet gendigtningen af Severine peger ud mod en stiliseret popkulturel tegneserieæstetik. Endelig indeholder "De blå øjne" punkt c) i form af medierefleksivitet fx ved en "læsevejledning" i begyndelsen eller ved at mime papirbogens "bladreeffekt" og dermed pege på sin egen digitale fysikalitet eller mangel på samme.

Digital litteratur for børn i en intermedial forståelsesramme accentuerer, at også litteratur præget af samtidig tilstedeværelse af forskellige udtryksformer er kommunikation, der tilbyder refleksions- og erkendelsespotentiale. Den intermediale tilgang er en måde at forstå fiktion på og rører ved sansernes hierarki ved at tildele både visuelle, auditive og taktile sanseappeller vægt i læse- og fortolkningsprocessen. Derfor er det bemærkelsesværdigt, at tilgangen kun i yderst begrænset omfang er tænkt ind i litteraturdidaktiske sammenhænge (fx Bönnighausen og Rösch, 2004; Vandermeersche og Soetaert, 2011) og slet ikke i forhold til modersmålsundervisningen i grundskolen i en dansk kontekst. Hvorfor og hvordan digital litteratur kan være indhold i danskundervisningen, vil blive belyst i det følgende. Først ud fra en analyse af de tidligere nævnte to nye begrebsanvendelser i Fælles Mål og dernæst ud fra tre praksisnære principper for intermedial litteraturdidaktik med "De blå øjne" som eksempel.

3 Mere herom i min ph.d.-afhandling Mellemværender. Litteratur for børn og unge midt i en medietid: Intermedialitet, materialitet og litteraturdidaktiske perspektiver, Aarhus Universitet 2017. 


\section{Indholdet og litteraturbegrebet i danskfaget under forandring}

I den seneste revidering af danskfagets curriculum Fælles Mål for faget dansk (Undervisningsministeriet 2014a og b) er der to elementer, der peger ind i en gentænkning af litteraturundervisningens genstandsfelt og legitimering. For det første beskrives fagets indhold to gange i formålsparagraffen som "litteratur og andre æstetiske tekster, fagtekster, sprog og kommunikation" (Undervisningsministeriet 2014a, stk. 1 og stk. 2). For det andet anvendes begrebet'multimodalitet' for første gang i fagets læreplan. Disse to elementer har betydning for definering af fagets indhold og stofområder, for litteraturbegrebet og for danskundervisningen. Derfor er det bemærkelsesværdigt, at artikler og bøger (fx Raahauge, 2014; Rytter, 2015; Nielsen, 2015; Illum Hansen, 2015; Carlsen, 2015; Olsen, 2016 og Bundsgaard, 2016), der behandler de Fælles Mål i dansk slet ikke eller kun i meget begrænset omfang tematiserer sådanne nye begrebsanvendelser og deres mulige vægtforskydninger i faget. Begrundelsen herfor kan være, at diskussionerne i højere grad har været og er optaget af læringsmålstyringen og det principielle ved kompetencemål og kompetencetilgangen i det hele taget. Dermed har der været mere vægt på at diskutere de principielle rammer for den didaktiske tænkning end på indholdet, hvilket tillige medfører et fokus på almendidaktiske frem for fagdidaktiske problemstillinger. Jeg vil i det følgende analysere den del af fagets indhold, der angår det litterære felt, og diskutere, hvad der kan være indeholdt $\mathrm{i}$ betegnelsen "litteratur og andre æstetiske tekster" og begrebet "multimodalitet" med fokus på at sætte disse to elementer i relation til digital litteratur for børn. For hvordan defineres disse nye faglige elementer, og hvordan prioriteres de? Og hvilke konsekvenser for litteraturbegrebet og for danskundervisningen får de?

\section{Dansk defineres som kommunikationsfag}

Hvor danskfagets indhold i formålsparagraffen i de tidligere Fælles Mål Dansk (Undervisningsministeriet, 2009) blev betegnet som "sprog, litteratur og andre udtryksformer" (stk. 1), så må vendingen "litteratur og andre æstetiske tekster, fagtekster, sprog og kommunikation" betyde dels en udvidelse af og dels en bestræbelse på at præcisere fagets indhold. Idet fagtekster sættes på linje med de tidligere anførte indholdselementer, må det betyde en opprioritering af denne form for tekster, hvilket også understøttes af faglig læsnings tydelige tilstedeværelse i såvel kompetenceområdet "Læs- 
ning" som i Læseplanen (Undervisningsministeriet, 2014b) og Vejledningen (Undervisningsministeriet, 2014c). Dertil kommer det nye indholdselement "kommunikation". For en umiddelbar betragtning kan ekspliciteringen af "kommunikation" virke redundant, eftersom de andre indholdselementer er kommunikative per se. Læser man Fælles Mål for faget dansk i sin helhed og vejledningen i særdeleshed, så bliver det tydeligt, at begrebet er tilført for at fundere danskfaget som et kommunikationsfag. Det bliver eksempelvis slået fast i det første afsnit i vejledningen med overskriften "Danskfagets identitet og rolle":

\section{"Fagets identitet omhandler sprog og tekster i kontekst. Tekster omfatter i denne sammenhæng både mono- og multimodale tek- ster, dvs. tekster, der er produceret i skrift, tale, billede og lyd. I arbejdet med tekster fokuseres der på at undersøge, forstå og anvende sproget ved at læse, skrive, tale, lytte og producere tek- ster. Desuden lægges der vægt på at undersøge og fortolke litte- ratur (herunder den danske litteraturs kanon) og andre æstetiske tekster (fx film og billeder) samt kommunikere med krop, stemme og sprog. I en vis forstand kan der argumenteres for, at dansk- faget overordnet set er et kommunikationsfag, og der arbejdes således med et udvidet tekstbegreb." (Undervisningsministeriet, 2014c, mine understregninger)}

Her i vejledningen defineres danskfaget således som et kommunikationsfag, om end der retorisk forekommer to styrkemarkører i form af "i en vis forstand" og "overordnet set", der bløder udsagnet lidt op. Det samme er tilfældet med anvendelsen af passiv, jf. "kan der argumenteres for", idet agens bliver udtydelig: Hvem argumenterer for dette? Det umiddelbare svar er naturligvis Ministeriet for børn, undervisning og ligestilling, som har nedsat arbejdsgruppen og udvalgt fagpersoner til at udarbejde Fælles Mål. Vejledningen har - som ordet siger - vejledende karakter, men den udstikker alligevel en retning og fremstiller sammen med læreplanen i sin helhed danskfaget som et kommunikationsfag, hvilket er i modsætning til den tidligere læreplan. I den tidligere vejledning blev indholdet bl.a. beskrevet således: "Sproget er danskfagets overordnede kerne, og litteraturen er fagets midtpunkt" (Undervisningsministeriet, 2009, s. 62). Hermed blev det indholdsmæssige omdrejningspunkt tætpakket af sprog og litteratur. Med den seneste læreplan nedtones den litterære og æstetiske side af danskfaget 
imidlertid til fordel for den kommunikative. Hermed sker der en accentforskydning i det spændingsfelt, danskfaget altid har været placeret i, imellem et hermeneutisk og kultur- og litteraturvidenskabeligt fag og et kommunikativt og sprogvidenskabeligt fag, henimod sidstnævnte.

\section{Det udvidede tekstbegreb udvides igen - og en inkluderende litteraturforståelse} Med fremhævningen af faget som et kommunikationsfag understøttes også læreplanens tekstsyn, der karakteriseres som "et udvidet tekstbegreb" (se understregning ovenfor). Det understøttes af læseplanens indledning: "I dansk arbejdes med begrebet tekst. Tekst omfatter i denne sammenhæng både mono- og multimodale tekster, der er produceret i skrift, tale, billede og lyd, fx film, hjemmesider, artikler, taler, fotos osv." (Undervisningsministeriet, 2014b, s. 3). Det udvidede tekstbegreb fra 70'erne oplever dermed fornyet aktualitet i 2010'erne, hvor det udvides endnu en gang med fx hjemmesider og sociale mediers tekster, hvilket afspejler den samfundsmæssige udvikling og tekstmangfoldighed. Det medfører desuden en mulig revurdering af tekstbegrebet og diskussionen af litteraturs legitimering.

Som tidligere fremhævet indgår litteraturbegrebet nu konsekvent i sammenstillingen "litteratur og andre æstetiske tekster". Ud over de to gange i formålsparagraffen forekommer denne sammenstilling seks gange i kompetencemål og færdigheds- og vidensmål for kompetenceområdet "Fortolkning". Det faktum, at "Fortolkning" nu er ét af fire kompetenceområder på linje med "Læsning", "Fremstilling" og "Kommunikation" er en nyskabelse, der har rod i fagets hermeneutiske fundering og tildeler - ud fra en konstruktiv tolkning - "Litteratur og andre æstetiske tekster" en central rolle i danskundervisningen. Desuden accentuerer den konsekvente sammensætning af "litteratur" og "andre æstetiske tekster" spørgsmålet om, hvilken relation der er imellem de to elementer og ordenes semantiske indhold. Betyder konjunktionen "og", at det drejer sig om to væsensforskellige indholdselementer? Eller betyder konjunktionen sideordning, identitet, lighed og lige prioritering af de to elementer?

Endnu et spørgsmål er, hvad "andre æstetiske tekster" mere specifikt indbefatter, og hvilken forståelse af æstetik ${ }^{4}$, denne nyskabelse baserer sig på. I vejledningen er der et muligt konkret svar på det første spørgsmål citeret

4 I artiklen her anvender jeg æstetikbegrebet med reference til Baumgarten og i forståelsen sanselig erkendelse, altså en opmærksomhed på menneskets sanser som adgang til erkendelse, refleksion og tænkning. Forskningen i æstetik har i de senere år fremhævet den æstetiske dimension i al kommunikation (fx i Thyssen et al., 2005 samt Bisgaard og Friberg, 2006), men 
ovenfor i parentesen "(fx film og billeder)", hvilket i de tidligere læreplaner blev betegnet som "andre udtryksformer". Her har den tidligere og også den nuværende vejledning foreslået andre konkretiseringer af dette element som fx computerspil og billedbøger. Digital litteratur for børn som eksemplificeret her i artiklen kunne være endnu et bud på dette indholdselement. Samlet peger vendingen "litteratur og andre æstetiske tekster" i retning af en gentænkning af litteraturbegrebet $i$ danskfaget henimod en inkluderende litteraturforståelse. En sådan åbning af litteraturforståelsen vil være i tråd med aktuel børnelitteraturforskning, hvor Nina Christensen argumenterer for en "litteraturopfattelse, der ud over skrift også forholder sig til litteratur som billede, lyd, animation, interaktion og mediebevidsthed" (Christensen, 2016, s. 9). I en medietid med digitale og teknologiske udviklinger bliver det nødvendigt at forlade forestillingen om litteratur for børn og unge som relativt stabile artefakter i bogform og åbne op for mere ustabile litterære former, der kun eller også eksisterer i elektroniske formater (Henkel, 2017b, s. 20), hvilket remedieringen af "De blå øjne" er et eksempel på. Med et bredt og heterogent litteraturbegreb vil skriftens selvfølgelige og ikke-diskuterede legitimering i danskfaget blive tematiseret.

\section{Multimodalitet - implicit og eksplicit}

Med Fælles Mål er begrebet multimodalitet for første gang blevet en del af danskfagets curriculum i folkeskolen såvel eksplicit som implicit. Eksempelvis lyder kompetencemålet for læsning efter 4. klassetrin: "Eleven kan læse multimodale tekster med henblik på oplevelse og faglig viden" (Undervisningsministeriet, 2014a), min understregning). Imidlertid er det bemærkelsesværdigt, at multimodale tekster ikke nævnes på de andre klassetrin, ligesom det kan undre, at det er under kompetenceområdet "Læsning", at multimodale tekster ekspliciteres og ikke ved kompetenceområderne "Fortolkning" og "Kommunikation". Anderledes konsekvent er det i kompetenceområdet "Fremstilling", hvor kompetencemålet ved alle klassetrin er varianter over sætningen: "Eleven kan udtrykke sig i skrift, tale, lyd og billede" (Undervisningsministeriet, 2014a). Her ekspliciteres multimodalitetsbegrebet således ikke, men det er tydeligt, at forestillingen om "Fremstilling" baserer sig på et udvidet tekstbegreb, som indoptager ligeværdige udtryksformer. Noget lignende gør sig gældende under kompetenceområ-

tillige peget på behovet for at "skærpe sensibiliteten for forskelle i typer af intentionalitet" (Pedersen, 2012). Diskussionen heraf ligger dog udenfor denne artikels rammer. 
det "Kommunikation", hvor elevens evne til at kommunikere mundtligt og med kropssprog samt dramaturgisk indsigt fremhæves. I dette område skal eleven $\mathrm{fx}$ have "viden om digital kommunikation i skrift, billede og lyd" efter 2. klassetrin og "viden om kendetegn ved tale, skrift samt ved visuelle og auditive modaliteter" efter 4. klassetrin. Dermed opskrives en multimodal tekstforståelse på forskellig vis i Fælles Mål, og der opstår en diskrepans i forhold til det skriftorienterede tekstbegreb, som de skriftlige afgangsprøver og de nationale test i læsning er udtryk for. Teksters sammensathed og udtryksformers ligeværdighed har dermed forskellig vægtning i læseplanen og i prøveøjemed. Når multimodalitet således altovervejende er til stede under "Læsning" og "Fremstilling", dominerer tillige forståelsen af danskfaget som et kommunikativt og sprogvidenskabeligt fag på bekostning af den hermeneutiske og litteraturvidenskabelige forståelse, som havde været mere fremtrædende, hvis elevernes interaktion med forskellige udtryksformer var blevet skrevet frem under "Fortolkning."

Betegnelserne "multimodal" og "multimodalitet" ekspliciteres i målene 15 gange, i læseplanen 11 gange og i vejledningen er der 30 forekomster. Som tidligere skrevet, er det tankevækkende, at denne forholdsvis nye tilgang til sprog og tekster ikke er blevet gjort til genstand for tematisering, efter den er blevet en del af danskfagets tekstforståelse. Tekster sammensat af forskellige udtryksformer er naturligvis ikke et nyt indhold i danskundervisningen, men den digitale og elektroniske udvikling medfører stadigt flere og mere avancerede sammensatte tekster, og det må være baggrunden for indoptagelsen af den multimodale tekstforståelse i den seneste læreplan. Multimodalitet anvendes især indenfor medie- og kommunikationsteori og bygger på semiotikken. Tankegangen og begrebsapparatet er i afgørende grad blevet udviklet af socialsemiotikeren M.A.K. Halliday, men er i en skole- og læringskontekst blevet videreudviklet af Gunther Kress, Theo van Leeuwen og Carey Jewitt til at beskrive kommunikation, der kombinerer flere semiotiske ressourcer og dermed den betydningsfrembringelse, der opstår med forskellige tegn. Helt grundlæggende betragter Kress alle tekster som multimodale, og han anser multimodalitet "as the normal state of human communication" (Kress, 2010, s. 1).

Det er sådanne præmisser, tekstforståelsen i danskfagets læreplan ser ud til at basere sig på med den gennemgående betoning af multimodalitet. Det er tillige en tekstforståelse, der afspejler den betydning, multimodale tekster har såvel i skole som i samfund. Med en multimodal tekstforståelse betones alle teksters og udtryksformers ligeværdighed, og tekster anses for at være 
kommunikation, hvilket er frugtbart i forhold til den udvikling, det aktuelle tekstlandskab befinder sig i. Imidlertid imødekommer den multimodale forståelsesramme ikke den særlige form for kommunikation, som kunst i særdeleshed og litteratur mere specifikt også er. Ikke sjældent har litteratur og anden kunst netop ikke til hensigt at kommunikere klart og entydigt, men gennem flertydige udsagn at mane til eftertanke og (selv)refleksion. ${ }^{5}$ Hvor multimodalitetsteori fremhæver det udvidede tekstbegreb i kommunikationsøjemed, så privilegerer intermedialitetsteori tekster som kunst og litteratur i erkendelsesøjemed. Tilsammen rører de ved forestillinger om hierarki og legitimering i forholdet mellem skrift og andre udtryksformer og peger på heterogenitet og pluralitet i forhold til teksters betydningsdannelse.

Et andet punkt, hvor den multimodale og intermediale tilgang divergerer, er i deres mediesyn. En konsekvens af den (social)semiotiske forståelse af multimodalitet er at forstå medier og i det hele taget betydningsdannelse som initieret af tegn, og tegn skal her ikke kun forstås som lingvistiske tegnsystemer, men omfatter også billeder, lyd osv. Intermedialitetsforskere som Mitchell og Elleström henviser også til semiotikken, men lader ikke denne stå alene. De fremhæver derudover de materielle og sensoriske kvaliteter ved et artefakts betydningsdannelse. En konsekvens heraf er, at den multimodale tilgang anskuer medier som sprog, hvorimod den intermediale tilgang i højere grad anskuer medier som miljøer, beskrevet med to mediemetaforer af Joshua Meyrowitz (Meyrowitz, 19976). At multimodalitetsperspektivet ser medier som sprog, kan man blandt andet se i bestræbelserne på at afdække visuelle designs "grammatik", som undertitlen til Kress og van Leeuwens bog Reading Images er, eller deres arbejde med at kortlægge farvernes "grammatik," som de har skrevet en artikel om (Kress og van Leeuwen, 2002). Her er der vægt på mediets repræsentation og de strukturer, det benytter. At intermedialitetsperspektivet heroverfor ser medier som miljøer, medfører vægt på forholdet mellem form, indhold og medie og dermed også den kontekst, som teksten optræder i. Hermed kommer der i eksemplet med "De blå øjne" også fokus på elevernes multisensoriske interaktion med fortællingen og i det hele taget på, hvordan læsningen via skærm har indflydelse på læse-

$5 \quad$ Intermedialitetsforskeren Jørgen Bruhn skriver fx: "the purpose of art and literature is very often to blur the very communicative messages a media product apparently sends" (Bruhn, 2016, s. 18). Og den 'materielle hermeneutiker' Jerome McGann beskriver fx, hvordan litterære tekster reflekterer læseren ved at: "turn readers back upon themselves" (McGann, 1991, s. 10-11).

6 Det skal nævnes, at Meyrowitz udkrystalliserer en tredje mediemetafor i form af medier som neutrale kanaler (Meyrowitz, 1997). 
kulturen i klasserummet. Skematisk og med den risiko for forsimplinger, som modeller altid kan have, kan spændingsfeltet mellem multimodalitetsog intermedialitetsteori sætte sådan op:

\begin{tabular}{|c|c|c|}
\hline & Multimodalitet & Intermedialitet \\
\hline Genstandsfelt & Alle tekster & Litteratur og anden kunst \\
\hline Tekstbegreb & Det udvidede tekstbegreb & Privilegerer litteratur og andre æstetiske tekster \\
\hline Udgangspunkt & $\begin{array}{l}\text { Teori om sammensatte tekster og deres } \\
\text { forskellige semiotiske ressourcer med henblik } \\
\text { på kommunikation }\end{array}$ & $\begin{array}{l}\text { Teori om tværæstetisk og tvermedial } \\
\text { betydningsdannelse og mulig erkendelse } \\
\text { herigennem }\end{array}$ \\
\hline Teoretisk forankring & $\begin{array}{l}\text { Semiotik og socialsemiotik } \\
\text { M.A.K Halliday, Gunter Kress, Theo van } \\
\text { Leeuwen og Carev Jewitt }\end{array}$ & $\begin{array}{l}\text { Kunstvidenskab med inspiration fra } \\
\text { medievidenskab } \\
\text { WJ.T. Mitchell, Lars Elleström og Jørgen } \\
\text { Bruhn }\end{array}$ \\
\hline \multicolumn{3}{|l|}{ I danskfaget } \\
\hline \multirow[t]{2}{*}{$\begin{array}{l}\text { Formål med at lrese } \\
\text { litteratur }\end{array}$} & $\begin{array}{l}\text { Kommunikation } \\
\text { (Litteratur som middel) }\end{array}$ & $\begin{array}{l}\text { Møde udsagn om at være menneske } \mathrm{i} \text { verden } \\
\text { (Litteratur som mál) }\end{array}$ \\
\hline & Alle multimodale tekster & Litteratur og andre æstetiske tekster \\
\hline Fagforståelse & Et kommunikativt og sprogvidenskabeligt fag & $\begin{array}{l}\text { Et hermeneutisk, kultur- og } \\
\text { litteraturvidenskabeligt fag }\end{array}$ \\
\hline
\end{tabular}

Illustration 5: Model over spændingsfelter i hhv. multimodalitets- og intermedialitetsteori

Ifølge Ellen Krogh og med henvisning til Lars-Henrik Schmidt er fagdidaktisk refleksion "defineret ved sin gøren, ved rummet mellem teoretisk blik og genstand, frem for ved genstanden i sig selv eller teoribygningen" (Krogh, 2012, s. 37). I det følgende vil jeg komme rummet mellem teoretisk blik og genstand endnu nærmere ved at gå fra de snævre fagdidaktiske spørgsmål, der orienterer sig mod formål, mål, begrundelser og indhold, til det bredere spørgsmål, der orienterer sig mod metoder og organisationsformer og dermed den konkrete planlægning og begrundelsesovervejelser herover.

\section{Intermedial litteraturdidaktik: Sanse, sammenligne og skabe}

Litteraturundervisning er ikke vilkårlig, men situeret i en ramme, hvor et indhold er valgt i samklang med formål for og mål med undervisningen, og disse begrundelsesovervejelser har nogle metodiske konsekvenser. Når undervisningen er indlagt $i$ en intermedial forståelsesramme, det indholdsmæssige genstandsfelt er digital litteratur for børn og kompetenceområdet "Fortolkning", og begrebet multimodalitet i Fælles Mål tillægges vægt, får 
det konsekvenser for danskundervisningen. I det følgende søger jeg derfor at operationalisere den intermediale tilgang ind i tre praksisnære principper for litteraturundervisning med "De blå øjne" som eksempel", som fokuserer på elevernes arbejde med tværæstetisk og tværmedial betydningsdannelse.

\section{A. Sanse: At læse, høre, mærke og se litteratur}

Ud fra den intermediale tilgang tillægges materialitet, perception og kognition - jf. citat af Elleström tidligere - afgørende vægt i betydningsdannelsen. To præmisser for intermedial litteraturdidaktik, som kan afledes heraf, er: 1) mediet, teksten er indlejret $i$, indgår på betydningsdannelsesniveauet, og 2) litteratur læses og perciperes med mange sanser. Derfor bliver oplevelse af og sansning i forhold til litteraturen central og danner udgangspunkt for det indledende litteraturarbejde, der har som formål, at eleverne oplever og nænsomt læser "De blå øjne" med sanserne forrest.

I forløbet med "De blå øjne" gør eleverne dette ved at læse, høre, se og interagere med såvel den skrevne version, Karen Blixens mundtlige version som den digitale version af "De blå øjne" på forskellige vis. Helt konkret udvælger de i Blixens fortælling på skrift to opmærksomhedspunkter: 1. En afgørende sætning (dvs. en sætning, som eleven vurderer, er særlig vigtig for fortællingen). 2. Et centralt sted i fortællingen (dvs. noget, eleven undrer sig over eller gerne vil undersøge nærmere. Et sted, eleven finder fascinerende eller gerne vil stille spørgsmål til). Eleverne fremlægger i grupper deres opmærksomhedspunkter, argumenterer for deres valg og bliver i grupperne enige om to fælles opmærksomhedspunkter, som de efterfølgende undersøger i forhold til den mundtlige og den digitale version. Hensigten er, at eleverne selvstændigt sanser og forholder sig til fortællingen, og hvordan den ændrer æstetisk dragt i de forskellige versioner. En anden opgave i denne første fase med fokus på sansningen af "De blå øjne" er at arbejde med at opleve, se, læse, høre og røre ved den digitale version. Under og efter dette litteraturarbejde skal eleverne arbejde med fortællingens forskellige stemninger og univers. Det gør de konkret ved at finde eksempler på fem forskellige stemninger, som fastholdes ved hjælp af screendumps, hvortil eleverne beskriver forskellige stemninger og hvilke sanser, der skaber disse

7 Dette er nogle overordnede principper. Yderligere konkretisering i form at undervisningsforløb målrettet udskolingen med specifikke opgaver og en læsning af "De blå øjne" kan findes på www.danskidybden.gyldendal.dk og en mere generel indføring i intermedial litteratur samt et undervisningsforløb med "De blå øjne" kan findes Dansk i dybden-hæftet med det samme navn (Henkel, 2017a). 
stemninger. Herefter vender eleverne tilbage til deres opmærksomhedspunkter fra tidligere og undersøger, hvordan opmærksomhedspunktet er fortolket i skrift, lyd, billede og eventuel interaktion i den digitale version. De forholder sig til og vurderer tekststedet, og hvordan det bidrager til fortællingen.

I denne indledende fase af litteraturarbejdet er der fokus på elevernes sansning og oplevelse af teksten, som vil danne baggrund for deres fortolkning. Denne nænsomme og sansebaserede måde "at læse" med øjnene, ørerne og fingrene på sætter fokus på elevens interaktion med teksten og dermed selve læsehandlingen, hvilket danner baggrund for det analytiske arbejde i den næste fase.

\section{B. Sammenligne: analysere mellem udtryksformer}

At læse litteratur i danskundervisningen er en dobbeltbevægelse imellem værket i sig selv og dets kontekst. I eksemplet her med "De blå øjne" går bevægelsen imellem fortællingen og dens måde at artikulere sig på og den fagdidaktiske kontekst, den er situeret i. At arbejde med digital litteratur for børn i litteraturundervisningen vil blandt andet dreje sig om at undersøge, hvordan forholdet mellem tekstens indhold og udtryk "mikses" med Mitchells begreb fra tidligere, hvordan litteraturen tilgås, hvilket i dette tilfælde er igennem fingerspidsernes søgen over en glasskærm, og hvordan disse elementer medfører et særegent udsagn om at være menneske i verden.

Da "De blå øjne" er en remediering, bliver det væsentligt at arbejde med udvekslingen mellem former og indhold. Begrebet remediering er for alvor blevet indkredset og eksemplificeret af medieteoretikerne Jay David Bolter og Richard Grusin i Remediation. Understanding New Media fra 2000. Heri beskriver de, hvordan remediering er et komplekst forhold af rivalisering og samarbejde mellem medieformer og genrer, at nye og gamle medier låner fra og udvikler hinanden, og at remedieringer i princippet aldrig ender. Remediering, forstået som udveksling af genrer, former og indhold mellem forskellige medier er et definerende karakteristikum i nye digitale medier ifølge de to forfattere Bolter og Grusin (2000, s. 45), og Bolter spidsformulerer: "Remediation describes all various relationships of cooperation and competition, rivalry and homage, and can involve form as well as content" (Bolter, 2014, s. 427). Netop at undersøge, hvordan forskellige udtryksformer står i relation til hinanden, og hvordan genrer, former og indhold udvikles i dialog med forskellige udtryksformer, vil være omdrejningspunkt i en intermedial litteraturdidaktik. 
I "De blå øjne" foregår remedieringen imellem Blixens mundtlige fortælling, den skriftbårne fortælling (der findes i flere versioner), og den digitale fortælling. Tre forskellige medier og (mulige) genrer, som alle i forvejen er ganske åbne formater: Den mundtlige fortælling af Karen Blixen, der i kraft af intonation, rytme, pause og ikke mindst historisk situerethed forankrer fortællingen i en historisk tid. Den skriftbårne fortælling, der via ordvalg, syntaks osv. er mere objektiv og henvender sig til intellektet. Og endelig det digitale litteraturformat, der endnu er så nyt og ustabilt, at egne genreog mediespecifikke egenskaber ikke fremtræder som klare kategorier. Den digitale litterære fortælling afprøver og eksperimenterer med forskellige udtryksformer og disses forskellige sanseappeller og med interaktion i en montagelignende struktur. Ordene har de tre versioner til fælles. Eleverne kan dermed oplagt arbejde med dialogen mellem de forskellige versioner ved at opleve, sammenligne og fortolke dem hver for sig, og hvordan de spiller sammen og/eller udfordrer hinanden. Dermed undersøger de med Bolters begreber, hvordan versioner og udtryksformer såvel hylder hinanden som indgår samarbejde og konkurrerer. Desuden vies særlig opmærksomhed til den digitale version, hvor eleverne $\mathrm{fx}$ arbejder med udvalgte sceendumps, som de skal "læse, høre, mærke og se langsomt", dvs. undersøge, analysere og fortolke.

En konsekvens af intermedialitetsperspektivet er at gå til en tekst ud fra tværæstetiske analysesnit. En analytisk tilgang kan enten være diakron i bestræbelsen på at undersøge, hvordan det litterære artefakt er skabt af forskellige æstetiske udtryk (skrift, billede, lyd osv.), eller den kan tage et synkront udgangspunkt ved at se på kategorier, som går på tværs af de æstetiske udtryk i en bestræbelse på at overskride mulige udtryks- og mediespecifikke grænser. Den synkrone tilgang er vokset ud af den diakrone og søger ikke at underkende vigtigheden af de enkelte udtryksformers egenværdi. Imidlertid vil tværæstetiske og synkrone analysekategorier kunne indfange den samtidige tilstedeværelse af udtryksformer og vekslen mellem statiske, dynamiske og interaktive elementer, som fx "De blå øjne" i den digitale version besidder. Derfor vil analytiske nedslag som fx modsætninger og symboler i billede, skrift og lyd være relevante at undersøge, ligesom eleverne arbejder med rytme og pausering i enkelte sekvenser og i fx "bladre-rytmen" og igennem opgaver bliver bevidste om deres konkrete interaktion med teksten. Eleverne arbejder dermed såvel med den samtidige tilstedeværelse af forskellige udtryksformer og også med udtryksformernes egenart og undersøger, hvilke konsekvenser dette får for de livstolkninger, teksten 
tilbyder. Arbejdet med fortællingens livstolkning foregår helt konkret, ved at eleverne "Går på spørgsmålstrappen", dvs. stiller spørgsmål på forskellige abstraktionsniveauer til teksten: Kom i gang-spørgsmål, dvs. spørgsmål, hvor svaret kan findes i teksten; genkendelsesspørgsmål, dvs. spørgsmål til noget i teksten, eleven kender fra sit eget liv; refleksionsspørgsmål, dvs. spørgsmål, hvor svaret findes mellem linjerne; og store spørgsmål, dvs. spørgsmål til det at være menneske, til dilemmaer eller udfordringer, som teksten lægger op til (Henkel, 2011, s. 58-59). Efter eleverne har stillet spørgsmålene vurderer de og vælger et til to spørgsmål, som de finder særligt vigtige at få svar på, og fortolker fortællingen herudfra. Herefter arbejder de med nogle refleksioner over forholdet mellem tekstens verden og deres egen verden, hvilket er særlig relevant, når teksten er skrevet af en kanoniseret forfatter.

\section{Skabe: Selv skabe en intermedial gendigtning}

I de to første faser i forløbet, sanse og sammenligne, har eleverne altovervejende perciperet litteratur, så nu skal de selv prøve kræfter med at producere en intermedial fortælling. Det gør de i form af at lave en multimodal remediering af "Glasskabet" (1847) af B.S. Ingemann. Denne fortælling er valgt, fordi den har nogle tema- og motivmæssige sammenfald med "De blå øjne" i forhold til blandt andet relationer mellem mennesker og øjemotivet, men også et radikalt andet udsagn. At percipere og producere anses dermed som to sider af samme sag, ligesom kompetenceområdet "Fremstilling", med det ofte anførte kompetencemål: "Eleven kan udtrykke sig i skrift, tale, lyd og billede", tilgodeses med denne produktive del af forløbet. Der er en særlig pointe $i$, at eleverne selv skaber en intermedial gendigtning efter først at have sanset, sammenlignet og fortolket en anden, idet de konstruktivt kan anvende de fremanalyserede virkemidler i deres egen genfortælling og selv arbejde med den enkelte udtryksforms forcer og svagheder samt skabe narrative forløb med en bred palet af udtryksformer. Kriterierne for elevernes gendigtninger vil derfor være at kombinere skrift, billede, lyd m.m. bevidst, hensigtsmæssigt og kreativt, at arbejde med symbolik og at indarbejde en oplæsning, der stemmer overens med deres fortolkning af Ingemanns fortælling. Afslutningsvis giver eleverne hinanden respons styret af læreren efter kriterierne: forholdet mellem udtryksformer, harmoni og disharmoni samt originalitet. 

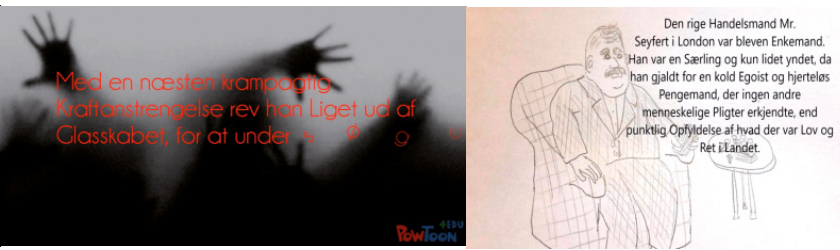

Illustration 6: Eksempler på screendumps fra 8.-klasse-elevers intermediale gendigtning af "Glasskabet" lavet $i$ videoredigeringsprogrammer eller med det digitale redskabsprogram PowToon.

\section{Afslutning}

Den aktuelle udvidelse af det udvidede tekstbegreb i Fælles Mål medfører dels stoftrængsel i danskfaget og dels, at alle tekster nivelleres og tildeles en kommunikerende hensigt. At indoptage den aktuelle tekstmangfoldighed - herunder digitale tekster - er helt nødvendigt i et moderne danskfag. Imidlertid kan en konsekvens af denne tekstmangfoldighed og den generelle kommunikations- og målstyringstænkning være, at litteratur bliver et middel til kompetencetilegnelse og udvikling af fx specifikke, målbare læsekompetencer. Heroverfor kan litteratur være et mål i sig selv. Litteratur og anden kunst indbyder til en særlig form for kommunikation, der er åben, flertydig og inviterer til oplevelse, (selv)refleksion og tilværelsestolkninger i dialog mellem værk og læser. Faktiske tekster står i modsætning hertil, idet de kommunikerer et mere tydeligt budskab i relationen mellem afsender og modtager. Den nye udvidelse af det udvidede tekstbegreb ser dermed ud til at invitere til diskussion af danskundervisningens indhold og eventuel revurdering af litteraturforståelsen.

Litteraturundervisningens genstandsfelt er i en dobbelttydig situation: På den ene side bliver der sat spørgsmålstegn ved litteraturs tidligere selvfølgelige placering i danskundervisningen pga. et udvidet og yderst inkluderende tekstbegreb i læreplanen, der fordrer ny legitimering af dette genstandsfelt. På den anden side udvider litteraturen sit felt i kraft af den digitale og teknologiske udvikling, hvilket medfører anderledes potentialer for realisering af litteratur med nye fagdidaktiske muligheder. Den digitale og remedierede version af "De blå øjne" er ét eksempel på et muligt indholdsvalg i det område i Fælles Mål for faget dansk, der betegnes "litteratur og andre æstetiske tekster". "De blå øjne" er ikke en radikalt ny form for litteratur, men litteratur i nye omgivelser, dvs. artikuleret på digitale præmisser og baseret på en forestilling om udtryksformers potentiale til at fortælle sammen og hver for sig. Digital litteratur efterspørger en nænsom og æstetisk læsemåde, 
dvs. at læse med sanserne forrest, i kraft af de multisensoriske henvendelsesformer.

I Fælles Mål for faget dansk kan man iagttage en tydelig integration og udbredelse af multimodalitet som begreb og som forståelsesramme for tekster, herunder litteratur, hvilket giver plads til remedieringer af fx ældre tekster, som i eksemplet med "De blå øjne". I artiklen her foreslås den multimodale tilgang kompletteret af en intermedial tilgang, idet denne tilskriver betydning til oplevelse og sansning af litteratur og anerkender mulighederne i kunstarters sammensatte former. Med en intermedial forståelsesramme vil litteraturs mulige refleksions- og erkendelsespotentiale blive aktualiseret, hvorimod den multimodale tilgang artikulerer teksters kommunikative hensigt. Hvor undervisningen ud fra en multimodal tilgang vil fokusere på, hvordan teksten hænger sammen som et tegnsystem, vil den ud fra den intermediale tilgang fokusere på teksten som et perspektiv på verden, som læseren sætter sig i dialog med. De to tilgange kan dermed udfordre, nuancere og berige hinanden. Hvor multimodalitetstænkningen i en dansk undervisningskontekst primært bygger på Kress og van Leeuwen og deres socialsemiotiske udgangspunkt og dermed har et forholdsvis fast defineret begrebsapparat i form af fx multimodal redundans og funktionel specialisering, er intermedialitetstænkningen mere vidtforgrenet og henter teoretisk legitimering i forskellige faglige kontekster. Dermed er en intermedial litteraturdidaktik først ved at tegne sine konturer, hvilket medfører en åben og afsøgende tilgang og invitation til udvikling af begreber og forståelsesrammer.

\section{Referencer}

Bell, A., Ensslin A., Ciccoricco, D., Rustad H., Laccetti, J., \& Pressman P. (2010). A [S]creed for Digital Fiction. Electronic book review. Lokaliseret 26. Oktober 2016 på http://electronicbookreview.com/thread/electropoetics/DFINative

Bisgaard, U. \& Friberg C. (red.) (2006). Det æstetiskes aktualitet. Frederiksberg: Multivers.

Blixen, K. (1942 og 2016). De blå øjne. Digital gendigning af Rune Højlund, Emma Hess Lerche og Morten Thunbo. København: Gyldendal Uddannelse.

Bolter, J.D. \& Grusin R. (2000). Remediation. Understanding New Media. Cambridge/London: The MIT Press.

Bolter, J.D. (2014). Remediation. I: Ryan, M-L., Emerson, L. \& Robertson, B., The Johns Hopkins Guide to Digital Media. Baltimore: Johns Hopkins University Press.

Bönnighausen, M. \& Rösch H. (2004). Intermedialität im Deutschunterricht. Baltsmannweiler: Schneider Verlag.

Bruhn, J. (2012). Litterær medialitetsanalyse. I: Stougaard Pedersen, B. \& Zacher Sørensen, M-M. (red.), Medialitet, intermedialitet og analyse. Akademiet for Æstetikfaglig forskeruddannelse, 50-68. 
Konturer af intermedial litteratur og litteraturdidaktik i Fælles Mål og ...

Bruhn, J. (2016). The Intermediality of Narrative Literature. Medialities Matter. London: Palgrave Macmillan.

Bundsgaard, J. (2016). Er dansk (stadig) et dannelsesfag? - Om baggrunde og fremtider med Forenklede Fælles Mål. Cursiv, 19, 89-112.

Carlsen, B.B. (2015). Nye mål og kompetencer i dansk. I: Rasmussen, J. Holm C. \& Rasch-Christensen A. (red.), Folkeskolen - efter reformen. København: Hans Reitzels Forlag.

Christensen, N. (2014). I bevægelse. Billedbøger og billedbogsforskning under forvandling. Tidskrift för litteraturvetenskap, 2, 5-18.

Christensen, N. (2016). Overgange. Børne- og ungdomslitteratur og barndomsopfattelser i bevægelse. Passage - Tidsskrift for litteratur og kritik, 75, 7-20.

DOI: http://dx.doi.org/10.7146/pas.v31i75.24162

Clüver, C. (2007). Intermediality and Interarts Studies. I: Arvidson, J., Askander, M., Bruhn, J. \& Führer, H., Changing Borders. Contemporary Positions in Intermediality. Lund: Intermedia Studies Press.

Elleström, L. (2010). The Modalities of Media: A Model for Understanding Intermedial Relations. I: Elleström, L. (red.), Media Borders, Multimodality and Intermediality. Hampshire: Palgrave Macmillan, 11-48.

Henkel, A.Q. (2011). Sammen om AT LÆSE LITTERATUR - Lærerens ressourcebog. København: Gyldendal.

Henkel, A.Q. (2016). "Ungdomslitteratur former(er) sig”. Passage. Tidsskrift for litteratur og kritik, 75, 77-92.

DOI: http://dx.doi.org/10.7146/pas.v31i75.24167

Henkel, A.Q. (2017a). Intermedial litteratur. Dansk i dybden. København: Gyldendal.

Henkel, A.Q. (2017b). Mellemværender. Litteratur for born og unge midt i en medietid: Intermedialitet, materialitet og litteraturdidaktiske perspektiver. Ph.d.-afhandling: Aarhus Universitet.

Illum Hansen, T. (2015). Dansk. Aarhus: Klim.

Ingemann, B.S. (1847). Glasskabet. I: Samlede Eventyr og Fortællinger. 2. udgave. København: Reitzel.

Jewitt, C. \& Kress G. (2003). Multimodal literacy. New York: Peter Lang Publishing.

Kress, G. (2010). Multimodality. A social semiotic approach to contemporary communication. London/New York: Routledge.

Kress, G. \& Leeuwen. T. (2001). Multimodal Discourse: The Modes and Media of Contemporary Communication. Oxford UK: Oxford University Press.

Kress, G. and Van Leeuwen, T. (1996). Reading Images - The Grammar of Visual Design. London: Routledge.

Kress, G. and Van Leeuwen, T. (2002). Colour as a semiotic mode: notes for a grammar of colour. Visual Communication, Vol. 1. No. 3.

Krogh, E. (2003). Et fag i moderniteten. Danskfagets didaktiske diskurser. Ph.d.-afhandling. Syddansk Universitet.

Krogh, E. (2012). Undersøgelser af fag i et fagdidaktisk perspektiv. Cursiv 7, 33-49.

McGann, J.J. (1991). The Textual Condition. Princeton: Princeton University Press.

Mitchell, W.J.T. (1994). Picture Theory: Essays on Verbal and Visual Representation. Chicago: University of Chicago Press.

Mitchell, W.J.T. (2005). There are no visual media. Journal of Visual Culture 4, 257-266.

Meyrowitz, J. (1997). Tre paradigmer i medieforskningen. Mediekultur, vol. 13, no. 26, 56-69.

Nielsen, B. (2015). Læringsmål i dansk. Frederiksberg: Samfundslitteratur.

Olsen, J.V. (2016). Professor: Fælles Mål er progressiv pædagogik. Folkeskolen, nr. 10. 
Konturer af intermedial litteratur og litteraturdidaktik i Fælles Mål og ...

Pedersen, B.S. (2012). Æstetisk erfaring, æstetisk kommunikation. I: Eriksson, B., Lund, J., Kaare Nielsen, H., Stougaard Pedersen, B. (red.), Æstetisering - forbindelser og forskelle. Aarhus: Klim, 268-278.

Rajewsky, I.O. (2002) Intermedialität. Tübingen: Francke.

Ringgaard, D. (2014). Litteratur. Aarhus: Aarhus Universitetsforlag.

Rippl, G. (red.). (2015). Handbook of Intermediality. Literature - Image - Sound - Music. Berlin/ Boston: De Gruyter.

Rustad, H.K. (2012). Digital litteratur. En innføring. Oslo: Cappelen Damm Akademisk.

Rytter, C. (2015). Bag om Fælles Mål - med litteraturbrillen på DanskLitt.dk, september.

Raahauge, J. (2014). Dansklærerforeningens Folkeskolesektions høringssvar til udkast til bekendtgørelse om formål, kompetencemål og færdigheds- og vidensmål for folkeskolens fag og emner. Lokaliseret 26. oktober 2016 på https://dansklf.dk/sites/default/files/ Hoeringssvar_om_nye_Faelles_Maal_kommentarerfra_faglige $\% 20$ foreninger_Bilag. pdf

Schwebs, T. (2014). Affordances of an App. A reading of The Fantastic Flying Books of Mr. Morris Lessmore. Nordic Journal of ChildLit Aesthetics. 5. Lokaliseret 12. januar 2015 på http://dx.doi.org/10.3402/blft.v5.24169

Simanowski, R. (2008). What is and to What End Do We Read Digital Literature? Dichtung Digital. Lokaliseret 26. oktober 2016 på http://www.dichtung-digital.org/2008/1-Simanowski.htm

Skyggebjerg, A.K. (2011). Er fagbøger en del af børnelitteraturen? I: Nedslag i børnelitteraturforskningen, 101-113.

Stichnothe, H. (2014). Engineering stories? A narratological approach to childrens's book apps. Nordic Journal of ChildLit Aesthetics. Vol. 5, 2014. Lokaliseret 12. januar 2015 på http://dx.doi.org/10.3402/blft.v5.23602

Sørensen, B. (2008). En fortælling om danskfaget. Dansk i folkeskolen gennem 100 år. København: Dansklærerforeningens Forlag.

Manresa, M. \& Real, N. (red.) (2015). Digital Literature for children. Texts, Readers and Educational Practices. Brussels: Peter Lang.

Thyssen, O. (red.) (2005). Æstetisk erfaring - tradition, teori, aktualitet. Frederiksberg: Samfundslitteratur.

Turrión, C. (2014). Multimedia book apps in a contemporary culture: commerce and innovation, continuity and rupture. Nordic Journal of ChildLit Aesthetics. Vol. 5. Lokaliseret 12. januar 2015 på http://dx.doi.org/10.3402/blft.v5.24426

Undervisningsministeriet (2009). Fælles Mål - 2009 - dansk. Undervisningsministeriets håndbogsserie, nr. 3.

Undervisningsministeriet (2014a). Fælles Mål for faget dansk. Lokaliseret 10. august 2016 på http://www.emu.dk/sites/default/files/Dansk\%20-\%20januar\%202016.pdf

Undervisningsministeriet (2014b). Læseplan for faget dansk. Lokaliseret 10. august 2016 på

http://www.emu.dk/sites/default/files/Dansk\%20L\%C3\%A6seplan_0.pdf

Undervisningsministeriet (2014c). Vejledning for faget dansk. Lokaliseret 10. august 2016 på

http://www.emu.dk/modul/vejledning-faget-dansk

Vandermeersche, G. \& Soetaert R. (2011). “Intermediality as Cultural Literacy and Teaching the Graphic Novel". CLCWeb: Comparative Literature and Culture 13.3. Lokaliseret 12. januar 2015 på http://dx.doi.org/10.7771/1481-4374.1806

Wolf, W. (2007). Intermediality. I: David, H., Jahn, M. \& Ryan, M-L. (red.), Routledge Encyclopedia of Narrative Theory. London: Routledge. 